\title{
Ichnology of the non-marine deposits of the Boskovice Basin (Carboniferous-Permian, Czech Republic)
}

\author{
RADEK MIKULÁŠ \& KAREL MARTÍNEK
}

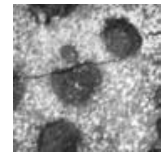

\begin{abstract}
In the area of the Boskovice Basin, simple ichnoassemblages and ichnofabric patterns characterize a suite of lacustrine and fluvial deposits. The succession of ichnofabrics enables us to correlate several sections in the northern part of the basin, supporting the correlation of the previously recognized Bačov, Míchov and Obora horizons. The mostly finegrained lacustrine deposits below bituminous limestones contain Planolites beverleyensis, Planolites montanus, amphibian footprints, and rare Cruziana problematica. Reddish sandstones, which can be interpreted as alluvial plain deposits, contain Planolites, Scoyenia, "star-like traces", and Diplocraterion. In the southern part of the basin, the coal-bearing strata are characterized by generally poor bioturbation, with isolated levels of "root spots" and Planolites. The lowermost strata of the overlying red-bed unit show intensive and rhythmical Planolites ichnofabric, the intensity and uniformity of which decrease upwards. - Key words: trace fossils, ichnofabric, Carboniferous, Permian, lacustrine and fluvial environment, Boskovice Basin.
\end{abstract}

MikUlÁš, R. \& MARTíneK, K. 2006. Ichnology of the non-marine deposits of the Boskovice Basin (Carboniferous-Permian, Czech Republic). Bulletin of Geosciences 81(1), 81-91. Czech Geological Survey, Prague. ISSN 1214-1119. Typescript received March 16, 2005; accepted in revised form January 12, 2006; issued March 31, 2006.

Radek Mikuláš, Academy of Sciences of the Czech Republic, Institute of Geology, Rozvojová 135, 16500 Praha 6, Czech Republic; mikulas@gli.cas.cz・Karel Martínek, Charles University, Faculty of Science, Institute of Geology and Palaeontology, Albertov 6, 12843 Praha 2, Czech Republic; karel@natur.cuni.cz.

The Boskovice Basin is several tens of kilometres long, and roughly north-south oriented (Fig. 1). It is filled only by non-marine sediments of Stephanian to Autunian age. Upper Palaeozoic fluvial and lacustrine deposits commonly show low-diversity ichnofabrics, but may contain abundant surface locomotion and grazing trace fossils. The documented localities of the Boskovice Basin show, however, that simple ichnofabrics can be useful for correlating sedimentological sections, and they can provide additional paleoenvironmental information. The aim of this paper is, therefore, to describe and interpret these trace fossils and ichnofabrics. Previous papers (e.g., Augusta \& Pokorný 1950) provided only a cursory examination of the biogenic sedimentary structures.

\section{Geological settings, localities, and trace fossil distribution}

Bačov quarries. - Three large abandoned quarries and several minor outcrops are located on the western foot of Bačov Hill, ca $3.5 \mathrm{~km} \mathrm{~N}$ of Boskovice. The succession of strata begins with non-bioturbated, thin bedded, fine-grained sandstones to sandy siltstones. It fines upwards into siltstones and sandy siltstones, and the colour changes from reddish to grey. Reddish fine-grained sandstones to sandy siltstones, followed by a fossil horizon of laminated bituminous limestones, comprise the upper interval (cf. Martínek et al. 2004a). This interval is characterized by rare root spots and layers spotted by Planolites montanus, and by a layer of sandy siltstone with common amphibian footprints occurring ca $8 \mathrm{~m}$ below the bituminous horizon.

Michov Hill. - This locality is situated on the SW slopes of Míchov Hill, ca $1.5 \mathrm{~km}$ NW of the previous site. Small permanent outcrops are limited to pits made by fossil collectors, which expose a bituminous fossil horizon, and to the bottoms of two narrow gorges. The documented section (Fig. 2) was excavated artificially. It starts with greyish, fine- to medium-grained sandstones that pass upwards into greyish and reddish mudstones and siltstones that yield plant detritus. The overlying interval of fine-grained sandstones is mostly reddish, with flaser bedding, and oscillation and current ripples. These rocks pass gradually into greyish siltstones alternating with fine- to medium-grained sandstones. The horizon of bituminous limestones lies approximately $10 \mathrm{~m}$ above the top of the documented profile (cf. Martínek et al. 2004a). The documented section yielded only a few slightly bioturbated horizons (Fig. 2) with 


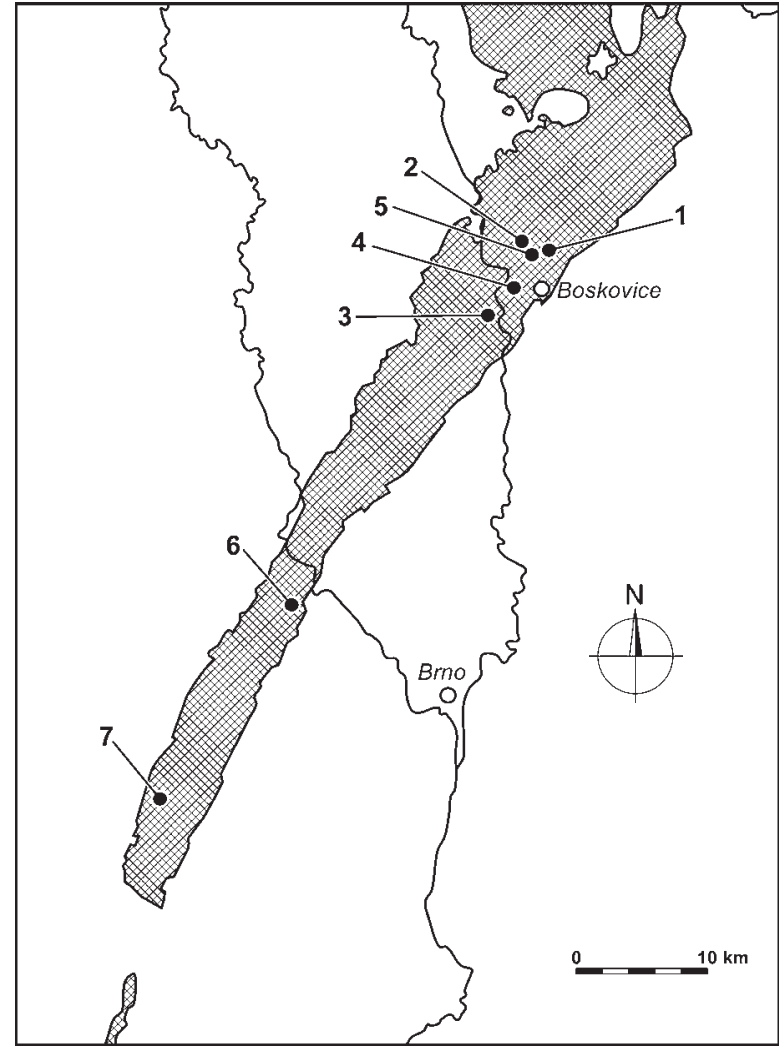

Figure 1. Sketch map of the Boskovice Basin, showing the position of the described localities. 1 - Bačov quarries, 2 - Míchov Hill, 3 - Obora, 4 - Svitávka, 5 - Semíč, 6 - Chudčice, 7 - Oslavany.

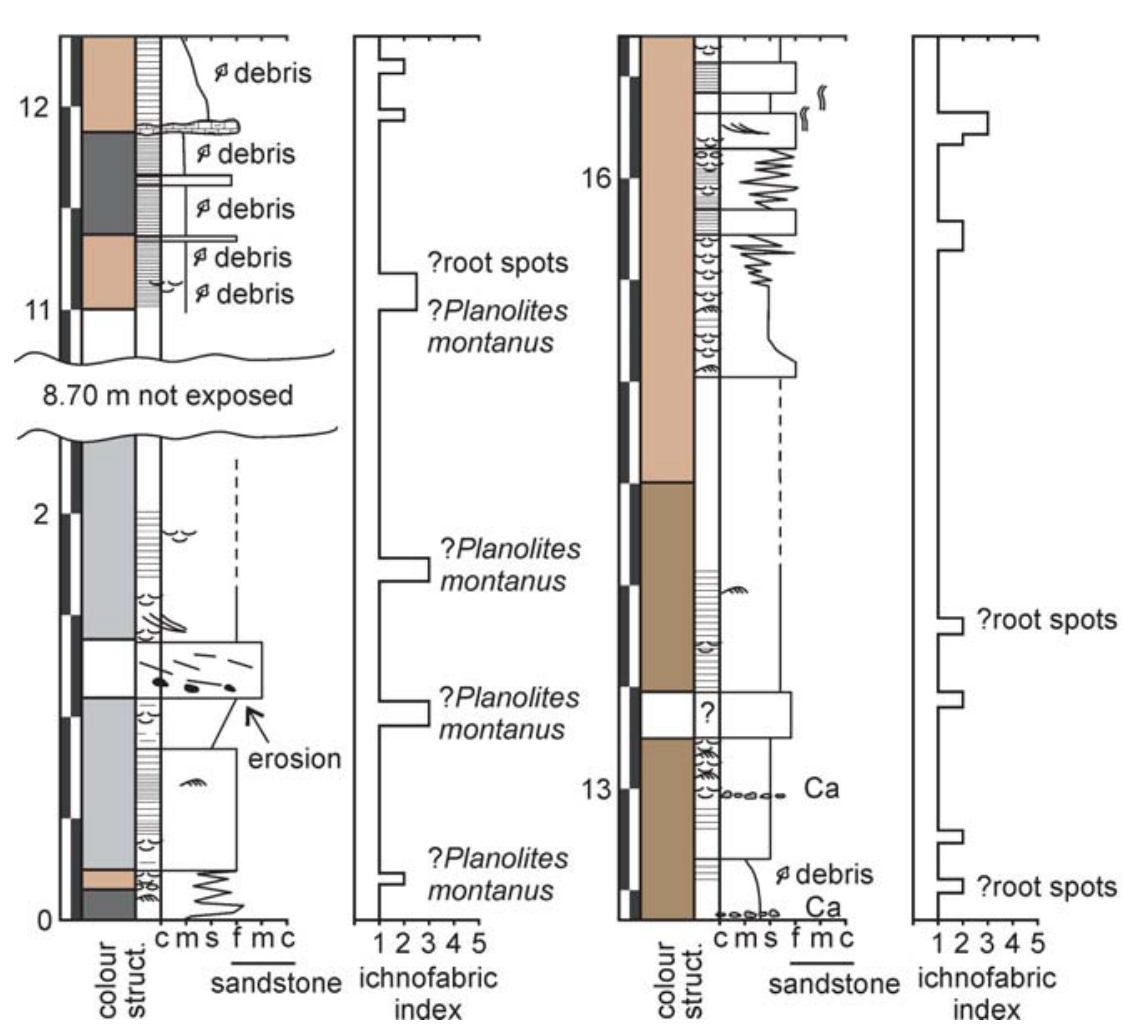

Planolites and root ichnofabrics. Permanent outcrops along the gorge of a small stream show that the layer of sandy siltstone $8-10 \mathrm{~m}$ below the bituminous horizon preserved numerous amphibian footprints and the trace fossil Cruziana problematica.

Obora near Boskovice. - This is a classic locality for fossil insects (e.g., Kukalová 1965) and amphibians (e.g., Klembara 1997). The section starts with laminated mudstones with rare flora and insect fauna. The following section is formed by grey to greenish-grey mudstones with rare layers of carbonate nodules and few intercalations of siltstone to fine-grained sandstone, rarely with flora. These beds, poor in fossils and bioturbation, are overlain by yellowish claystone, followed by a laminated yellow-brown mudstone-bearing amphibian crawling traces. A horizon of finely laminated bituminous limestones, about $180 \mathrm{~cm}$ thick, is the most fossiliferous layer of this locality, and overlies the mudstone unit (Martínek et al. 2004a).

The Míchov and Bačov horizons, including the Obora locality, have several common features: their sedimentological sections are very similar and dominated by lacustrine offshore facies, they belong to the single faunal biozone Xenacanthus decheni, they contain very similar xerophilous-dominated floral assemblages, and the same succession of ichnotaxa occurs in Bačov and Míchov sections. These horizons thus seem to represent a single stratigraphic unit (Martínek et al. 2004a, b).

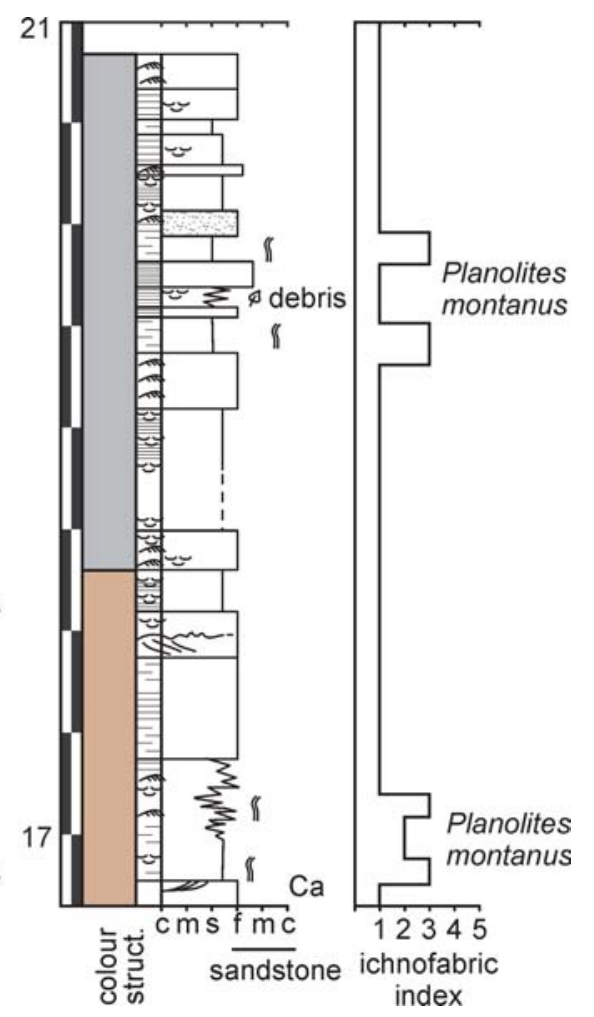

Figure 2. Míchov Hill, section 7: lithology, palaeontology, and ichnology. Scale in metres. See Fig. 6 for explanation. 

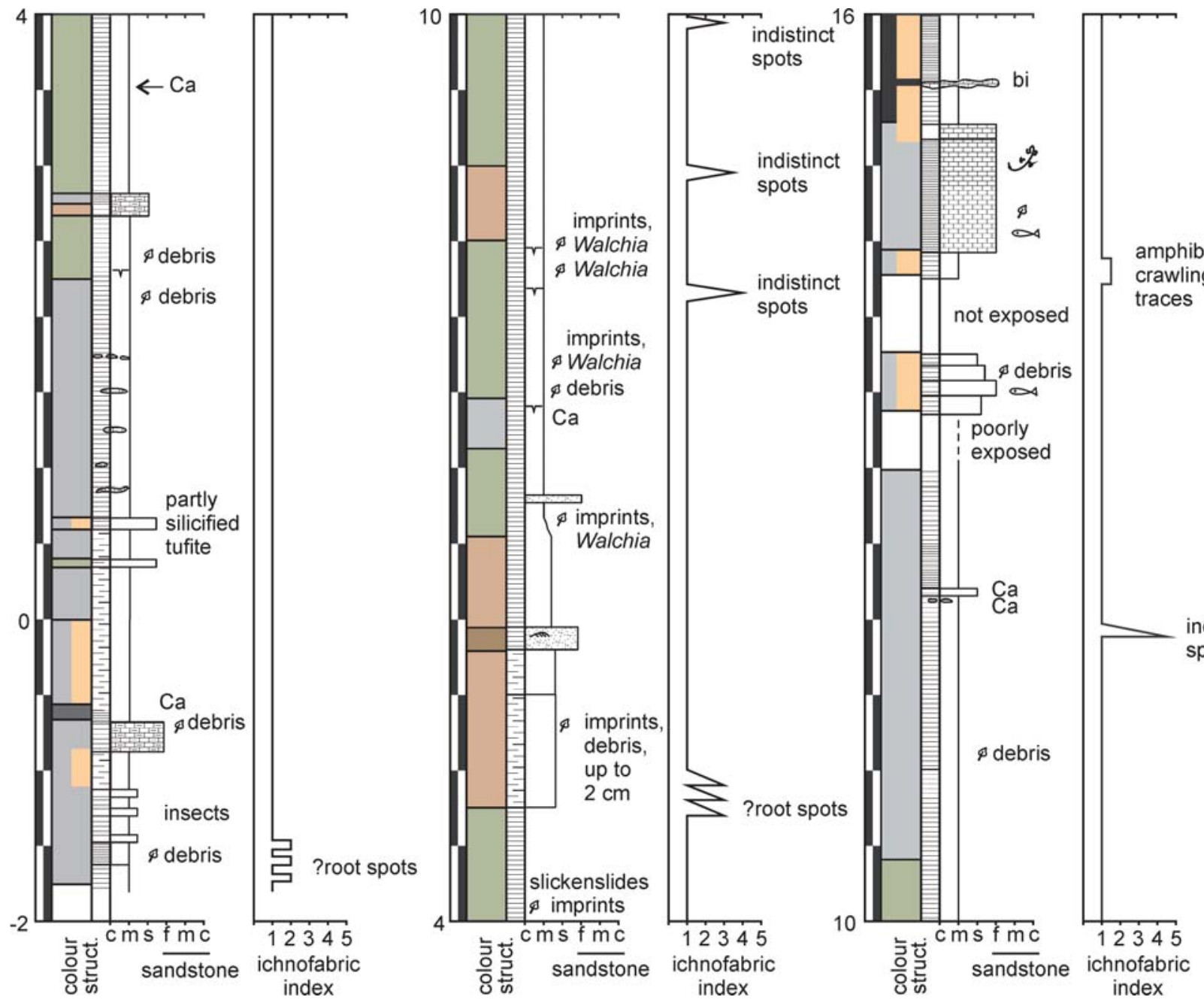

Figure 3. Section at the Obora site: lithology, palaeontology, and ichnology. Scale in metres. See Fig. 6 for explanation.

Svitávka. - Several small and large outcrops occur on the southern slope of Svitávka Hill. Numerous lithotypes and several fossiliferous layers are exposed there. The ichnologic content of fine-grained rocks (Martínek et al. 2004a) is very sparse. Small, long abandoned quarries of thickbedded, reddish, medium-grained sandstones yielded nice samples of the "large Planolites" ichnofabric. Analogous rocks were used for constructing the row of small houses just on the foothill. In the building stones, the trace fossils Planolites beverleyensis, ?Scoyenia isp., "star-like trace", and Diplocraterion isp. were found. The sections are dominated by lacustrine deposits. The flora is mostly xerophilous, and though the hygrophilous flora is rare, palynological data point to more hygrophilous species. These data are interpreted as reflecting more arid climatic conditions in this part of the basin (Martínek et al. 2004a, b).

Semíč. - Small natural outcrops occur above the left bank of the Semíč Brook, ca $1 \mathrm{~km} \mathrm{~S}$ from Bačov Hill. The expo- sed rocks are represented mostly by laminated bituminous limestones with fauna and flora (Martínek et al. 2004a). They commonly contain large (up to $10 \mathrm{~mm}$ in width, and a maximum length of $8 \mathrm{~mm}$ ), moderately curved to meandering structures. As they are extremely flattened and affected by diagenetic processes, their nature is not quite clear but they may be preliminarily considered to represent dwelling burrows, or the coprolites of amphibians or fish.

Chudčice. - In the middle part of the basin, ca $10 \mathrm{~km} \mathrm{NW}$ from the centre of Brno, an old railway cutting exposes a relatively uniform suite of the Boskovice Basin sedimentary fill. It consists of siltstones with rare trace fossils (Planolites isp., "root spots") indicating sporadic "colonisation windows". A nearby temporary outcrop in the village exposed thin-bedded, reddish, fine-grained sandstones with a prominent, intensively bioturbated layer (Planolites isp., Palaeophycus isp.; cf. Martínek et al. 2004a). 


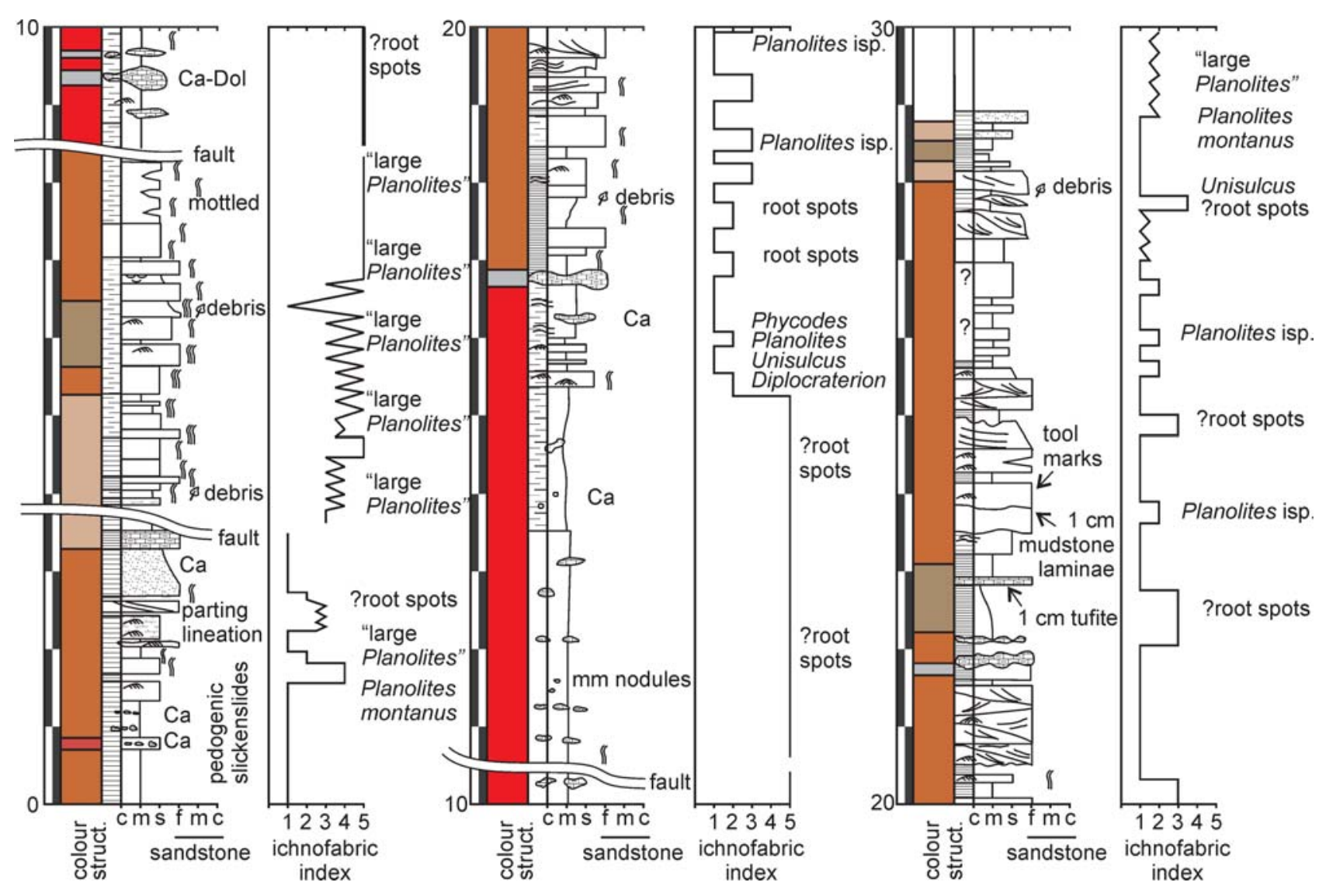

Figure 4. Oslavany, section III: lithology, palaeontology, and ichnology. Scale in metres. See Fig. 6 for explanation.

\section{sedimentary structures

$\mho \quad$ load casts
oscilation ripples
current ripples

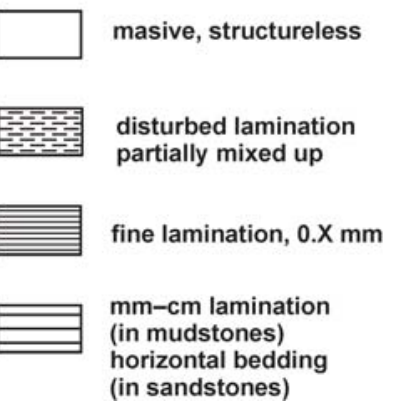

\section{fossils}

$\ell$ roots, rootlets

$\diamond \quad$ fish scales

$ه$ fish, fish bones, dents

Ф) terrestrial plants, debris

《I bioturbation (borrings,

$\int$ burrows, other ichnofossil)

$\iiint \quad$ intense bioturbation

\section{colours}

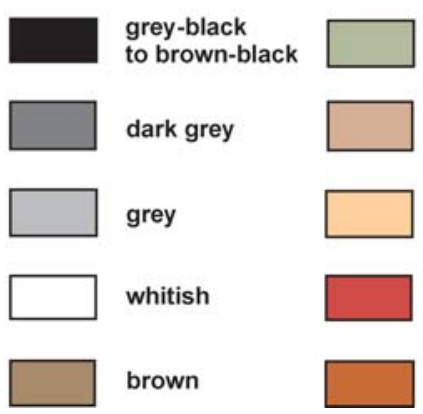

lithology

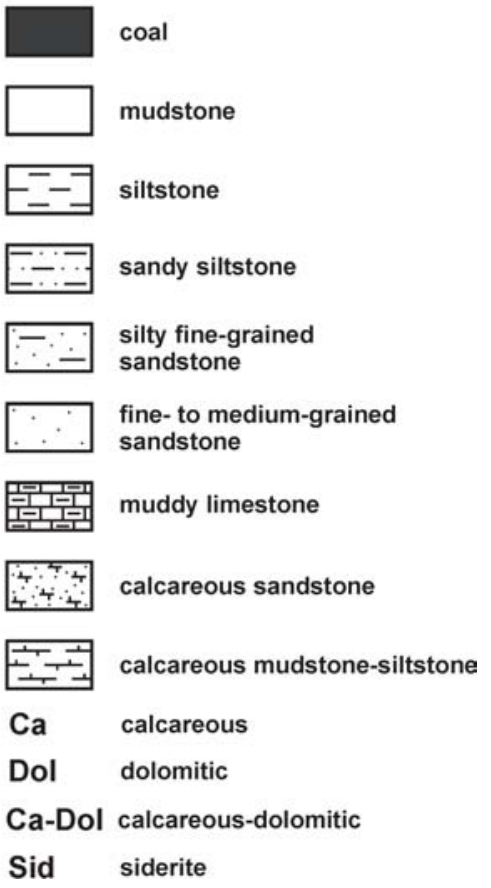

Figure 6. Legend to the sections depicted on Figs 2-5.

greenish-grey

light-brown,

grey-brown,

brown-grey

yellowish, weatheing to ochre

brown-red

red-brown 
Radek Mikuláš \& Karel Martínek • Ichnology of the non-marine deposits of the Boskovice Basin

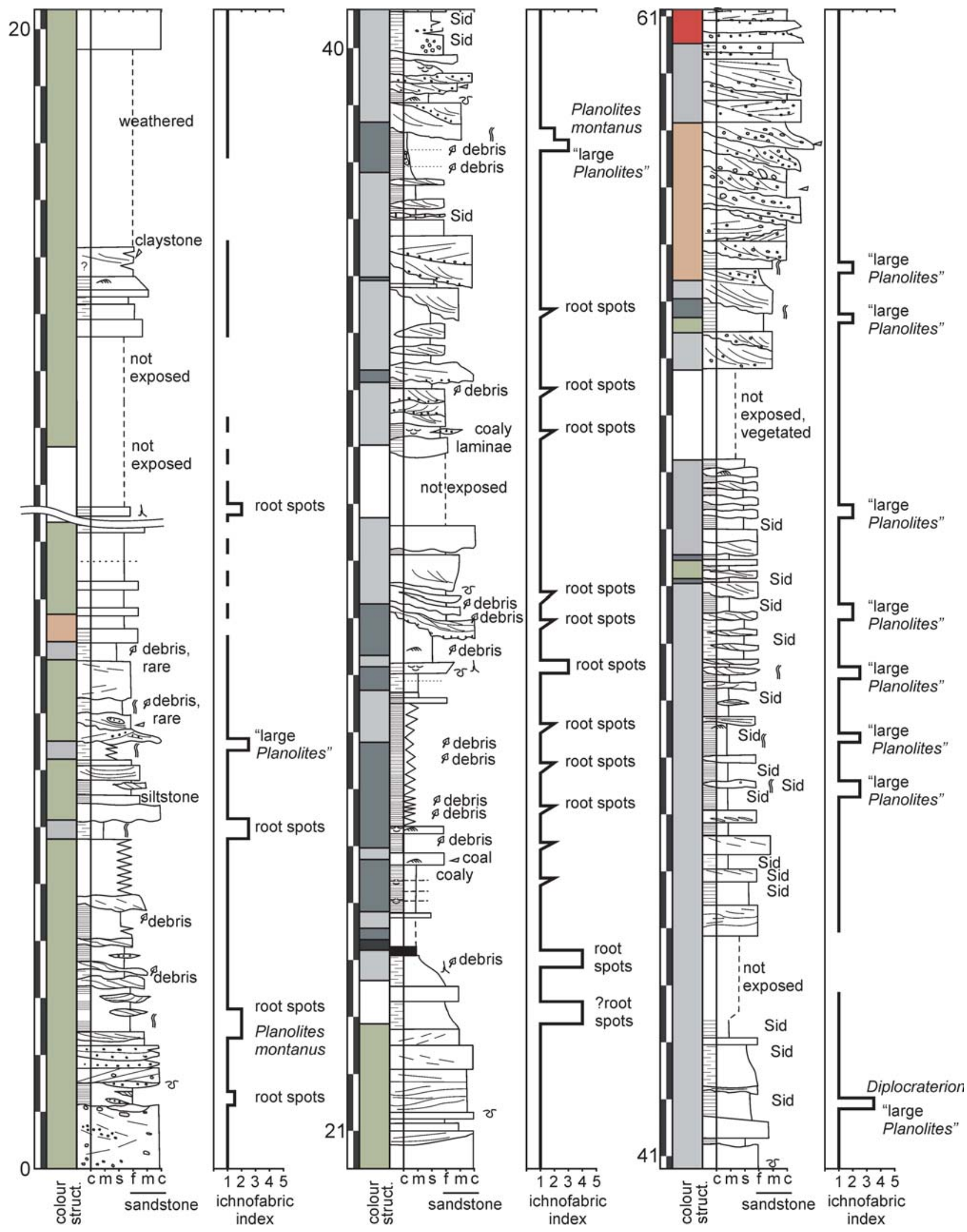

Figure 5. Oslavany, section I: lithology, palaeontology, and ichnology. Scale in metres. See Fig. 6 for explanation. 
The Chudčice section is dominated by laminated mudstone representing shallow lacustrine offshore/nearshore (mainly mudflat) transitions. Its flora is xerophilous. These data suggest more arid climatic conditions (Martínek et al. 2004a, b).

Oslavany. - Outcropping cliffs reveal several formations of the southern part of the Boskovice Basin on the left bank of the Oslava River, NE of the town of Oslavany (Pešek et al. 2001, Martínek et al. 2004a; Figs 4-5). The coal-bearing cycle (Rosice-Oslavany Formation; Fig. 5) consists of claystones, sandstones, and conglomerates, and includes three main horizons yielding remnants of flora. Layers rich in plant fossils have poorly preserved root ichnofabrics. Rhythmically alternating mudstones and fine-grained sandstones in the upper part of the cycle show at least seven colonisation windows used by the tracemaker of "large Planolites". Depositional environments include lacustrine delta (lower delta plain), swamp, and lacustrine offshore and distributary (fluvial) channels on an upper delta plain. The flora is almost entirely hygrophilous, pointing to a high water table. These data suggest deposition under humid climatic conditions (Martínek et al. 2004a, b). The overlying red-bed succession (Padochov Formation) starts with reddish mudstones with carbonate nodules and continues with alternating red siltstones and sandstones (Fig. 4). These layers show intensive and rhythmical Planolites ichnofabrics. The overlying layer of red mudstones with carbonate nodules seems to be completely bioturbated. This unit passes into red siltstones and sandstones with rhythmical Planolites ichnofabrics. Intensity and uniformity of the bioturbation pattern decrease upwards. The described section is characterised by lacustrine offshore/nearshore interfingering, anoxic offshore facies, high carbonate content, poor hygrophilous and xerophilous floral assemblage, and diversified fauna (including predators, such as sharks). These features are interpreted as indicative of a large, possibly hydrologically closed, lacustrine system with periods of eutrophication, and a more arid climatic setting (Martínek et al. 2004a, b).

The uppermost strata are exposed in large abandoned quarries, and consist of massive to thick-bedded arkoses of the upper part of the Padochov Formation. Only one layer with prominent bioturbation, represented by numerous specimens of Lockeia isp., was found in the section (i.e., in an intercalation of thin-bedded, poorly sorted, fine-grained arkoses within the massive arkoses).

\section{Systematic ichnology}

Collected material is housed in the Institute of Geology, AS CR, Prague.

\section{Amphibian crawling traces}

Material. - Two specimens from the Obora locality near Boskovice.

Description. - Three isolated series of shallow, straight or very slightly curved parallel striae (3-4 striae in each series) found in the upper bedding planes of the rock samples. Width of the series ca $15 \mathrm{~mm}$, length of striae up to $40 \mathrm{~mm}$.

Remarks. - Though formally attributable to the ichnogenus Monomorphichnus Crimes known chiefly from shallow marine Early Palaeozoic strata, the find may be reasonably interpreted as amphibian crawling traces; therefore, this informal designation is also kept in the Systematic ichnology.

\section{Amphibian footprints \\ Figures 7A, C}

Material. - Twelve specimens from the Míchov- 8 and Bačov-3 localities.

Description. - Medium-sized (several centimetres long and up to $20 \mathrm{~mm}$ wide), foot-like to flame-like imprints with three or four preserved "fingers", found on upper bedding planes. They show either a chaotic arrangement, or they form a series. However, these series are difficult to trace over longer distances: the individual footprints are at least $10 \mathrm{~cm}$ apart.

Remarks. - It is likely that these traces represent the poorly preserved footprints of amphibians (cf. Braddy \& Briggs 2002).

\section{Cruziana D'Orbigny, 1842}

\section{Cruziana problematica (Schindewolf, 1921)}

Material. - A single specimen from the Míchov-8 locality.

Description. - Moderately curved, bilobate ridge (convex hyporelief). Length $7 \mathrm{~cm}$, width $8-10 \mathrm{~mm}$. Surface bears

Figure 7. - A, C - amphibian footprints; A $-\times 0.5, \mathrm{C}-1.0$, Míchov Hill. $\bullet \mathrm{B}-$ bundled or incompletely preserved radial ("star-like") trace, $\times 0.8$, Svitávka - local reddish sandstone (building stone). $\bullet \mathrm{D}-$ ?Scoyenia isp., $\times 0.8$, Svitávka - building stone. $\bullet \mathrm{E}, \mathrm{F}-$ Planolites beverleyensis $($ Billings, 1862), $\times 1.1$, Svitávka - building stone. $\bullet \mathrm{G}-$ ?poorly preserved resting traces, $\times 1.0$, Oslavany III. $\bullet \mathrm{H}-$ ?Diplocraterion isp., $\times 1.1$, Oslavany III. 

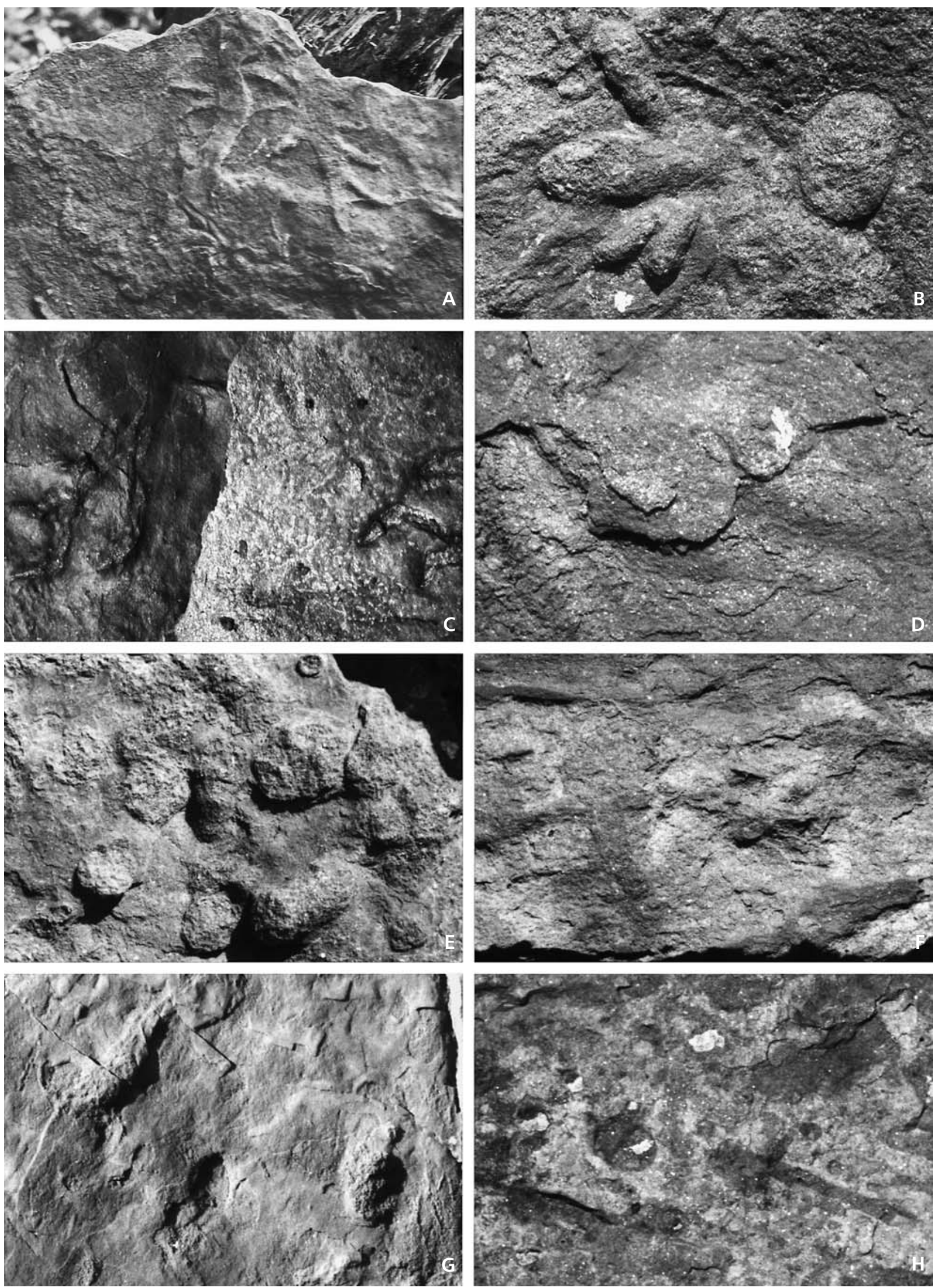
rather prominent transverse segmentation (approx. 2 "segments" per $\mathrm{cm})$. Relief is ca $2 \mathrm{~mm}$ high.

Remarks. - For the ichnotaxonomy of C. problematica see Keighley \& Pickerill (1996), and Mangano et al. (2002). Pollard (1988) regarded this ichnotaxon as typical of fluvial channels - flood plains of paralic basins.

\section{Diplocraterion Torell, 1870}

\section{Diplocraterion isp.}

Figure 8A, ?Figures 7H, 8G

Material. - Several tens of observations and collected specimens from the localities Oslavany I and III.

Description. - Pairs of cross-sections of vertical tubes, jointed with straight or curved cross-sections of spreite lamina. The cross-sections of the tubes are commonly 4-15 $\mathrm{mm}$ apart, and 1-2 $\mathrm{mm}$ in diameter.

Remarks. - These traces are most common in the beds where the bioturbation rate is generally high. They most likely represent horizontal cross-sections of Diplocraterion. For description, relations, and figures of this ichnogenus and particular ichnospecies see Häntzschel (1962), and Fillion \& Pickerill (1990).

\section{Lockeia James, 1879}

\section{Lockeia silliquaria James, 1879}

Figure 8E

Material. - One slab of fine-grained, clayey subgreywacke, bearing 12 specimens from the Oslavany IV locality.

Description. - Smooth, almond-shaped bulges preserved as low convex hyporeliefs. Dimensions of the bulges range from $4 \times 1 \mathrm{~mm}$ to $10 \times 2.5 \mathrm{~mm}$. The bulges show preferential orientation (i.e., more than a half of them are sub-parallel).

Remarks. - This morphologically simple trace is considered to be the resting trace of bivalves. For the description of this ichnogenus, including its origin and representatives, see Maples \& Suttner (1990), and Mangano et al. (2002).

\section{Palaeophycus Hall, 1847}

\section{?Palaeophycus tubularis Hall, 1847}

Material. - About 20 specimens (collected or observed in situ) from bituminous limestones at Míchov Hill-8, Bačov-2, Bačov-3, Obora near Boskovice, and Semíč.

Description. - Slightly to prominently curved or even meandering (2 meanders at maximum) smooth structures, contrasted by their light filling to the surrounding substrate (dark bituminous limestone). Wall lining is not visible, but the contrast between the fill of the bodies and the surrounding substrate is sharp. Tunnel diameters range from 5 to $8 \mathrm{~m}$, while the length of the preserved parts is up to $80 \mathrm{~mm}$.

Remarks. - Systematic determination of this form is difficult. In common with other trace fossil finds in carbonates, it is often difficult to distinguish the original morphology and material of the biogenic structure. In the present case, the structures may have resulted from tunnels, and, following the work of Pemberton \& Frey (1982), they may be classified as Palaeophycus, which represents domichnia of invertebrates. Otherwise, vertebrate coprolites (?amphibian) might result in the origin of comparable, smooth, curved or meandering structures.

\section{Planolites Nicholson, 1873}

\section{Planolites beverleyensis (Billings, 1862)} Figures 7E, F, 8A, C, D

Material. - Several tens of specimens (collected or observed in the field) from the localities Oslavany I and III.

Description. - Straight or moderately curved, smooth, exceptionally branching tunnels of circular outline, parallel to bedding, filled with material differing from the surrounding rock. Preserved as full reliefs, or as convex hyporeliefs when the rhythmical sedimentation allows. They occur solitary, but more often largely cover bedding planes. The diameter of the tunnels commonly ranges from 4 to $8 \mathrm{~mm}$, while the lengths of the preserved sections are up to $30 \mathrm{~mm}$. Tunnels present on one bed or bedding plane usually show a constant diameter.

Remarks. - The assignment of these trace fossils to $P$. beverleyensis follows the paper by Pemberton \& Frey (1982).

Figure 8. • A, C, D - Planolites beverleyensis (Billings, 1862), × 1.0, Oslavany III. • B - Diplocraterion isp., $\times 1.5$, Oslavany III. • E - Lockeia silliquaria James, 1879, $\times 1.3$, Oslavany IV. $\bullet \mathrm{F}, \mathrm{G}-$ Planolites montanus Richter, 1937, × 1.0, Oslavany. $\bullet \mathrm{H}-$ rootlets, $\times 1.8$, Oslavany III. 

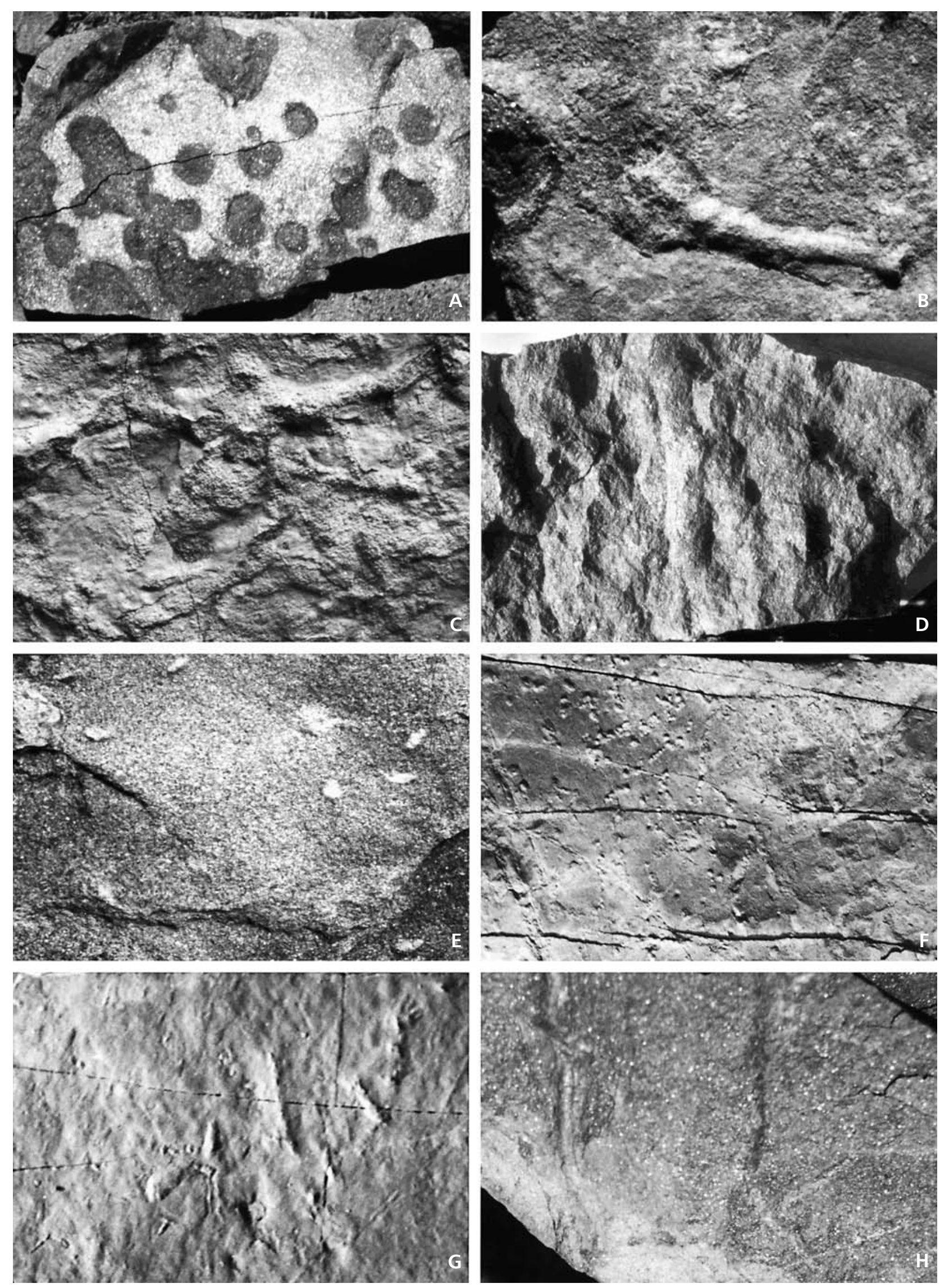
Because of the lack of further morphological information, the cross-sections of the tunnels corresponding to their diameters (without more information on branching and orientation) are determined as "large Planolites" in the profiles. Most of them probably correspond to the ichnospecies Planolites beverleyensis; while others show prevailing oblique components and can therefore be certainly classed as Planolites.

\section{Planolites montanus Richter, 1937}

Figures 8F, G

Material. - Several tens of specimens (collected and observed in situ) from the localities Míchov Hill-7 and Míchov Hill-8, Bačov-2 and Bačov-3, and Oslavany I and III.

Description. - Narrow, subhorizontal, smooth, simply to complexly curved passages, often branching, without wall lining, commonly occurring densely in the same layer. At lithological boundaries, the fill of the traces is often contrasted by colour from the surrounding rock. The diameters of the passages are 1-3 $\mathrm{mm}$, and the length of preserved sections usually up to $20 \mathrm{~mm}$.

Remarks. - The taxonomical assessment of this trace follows the work of Pemberton \& Frey (1982). Where the intensity of the bioturbation is higher, ichnotaxonomic assignments are doubtful or impossible.

\section{"Root spots"}

Material. - Hundreds of observations from nearly all the listed localities.

Description. - Irregular to subcircular spots of varying diameter (1-5 mm), which typically occur over large areas of beds. They may also be accompanied by horizontal, winding, or even branching "tapes". Some of these "tapes" contain preserved organic matter.

Remarks. - These structures can be best understood as spots generated by plant roots (cf. Bockelie 1994).

\section{Scoyenia White, 1929}

\section{?Scoyenia isp.}

Figure 7D

Material. - Several specimens on old sandstone walls in the village of Svitávka.
Description. - Wide (up to $15 \mathrm{~mm}$ ) cylindrical tunnels with thick wall lining and usually poorly preserved meniscate filling, and striated wall surfaces.

Remarks. - These traces are attributable to Scoyenia following the review by Frey et al. (1984).

\section{Discussion and conclusions}

In the northern part of the basin, the sections at the Bačov quarries and at Míchov Hill have common ichnologic characteristics: the successions start with mudstones and fine-grained sandstones, alternating rhythmically in several decimetre-thick beds. These are non-bioturbated except for a sparse record of short colonisation windows (ichnofabric index, i.i. $=2-3$ ) that are typically $30-80 \mathrm{~cm}$ apart in the section, and which are ichnotaxonomically characterized by Planolites montanus. The following succession consists of siltstones with carbonatic beds or nodule-rich layers. Colonization windows are poorly recognizable, showing average rhythmicity of 15 to $20 \mathrm{~cm}$. The overlying parts of the sections consist of fine-grained sandstones with ripples and cross-bedding. Trace fossils are well-preserved on their upper bedding planes (amphibian footprints, Planolites isp., and Cruziana problematica). A prominent horizon of bituminous limestones rich in fauna and flora lies 5-6 $\mathrm{m}$ above the sandstones with footprints. The limestone shows no trace fossils except for curved to meandering bodies (?coprolites; ?Palaeophycus isp.). The similarity of bioturbation in the two sites (regardless minor differences in lithology) shows that the bituminous limestones of both localities (i.e., so-called Bačov and Míchov fossil horizons) can be considered equivalent.

The classic fossil locality of Obora at Boskovice shows a different bioturbation pattern of the succession underlying the bituminous limestone horizon. Mudstones with undisturbed laminae prevail 2 to 15 metres below the bituminous limestones; they have only a few poorly recognizable bioturbated layers. Several decimetres below the fossil horizon, a layer with sparse crawling traces of amphibians occurs. Another prominent ichnoassemblage of the northern part of the graben fill is found in the reddish sandstones at the southern foothill of Svitávka Hill. It consists of Diplocraterion, Scoyenia, "star-like trace" and Planolites. These ichnotaxa refer to a "classic" Scoyenia Ichnofacies, and therefore suggest the presence of periodically flooded plains with a long-lasting influx of sand. At the same locality, grey mudstones underlying the fossiliferous layer of dark claystone show the alteration of probably plant bioturbation ("root spots") and animal colonization (Planolites montanus). In the middle part of the basin, richly bioturbated (Palaeophycus isp.) reddish siltstones to fine-grained sandstones were found at Chudčice. In the 
southern part of the basin, the classic outcrops at Oslavany are the most informative. The succession of the coal-bearing Rosice-Oslavany Formation is characterized by alternating episodes of plant bioturbation (root spots) and sediment feeding (Planolites), rarely also with dwelling burrows (Diplocraterion). The bioturbated layers are commonly divided by several metre-thick unbioturbated successions. The lowermost strata of the non-coal-bearing Padochov Formation shows intensive bioturbation ("large Planolites ichnofabric"; i.e., feeding traces, or occasional shelters from drying). The distance between the bioturbated layers is commonly ca $10 \mathrm{~cm}$. Subsequently, the regularity of the pattern decreases, and new ichnofabrics (rootlets; Diplocraterion) occur locally. In the upper part of the Padochov Formation, represented mostly by massive arkoses, a colonization window occupied by Lockeia isp. (bivalve traces showing preferential orientation to current) has been found.

\section{Acknowledgements}

We thank the official reviewers of the paper, Luis Buatois and Vladimír Prouza, for numerous helpful comments. Jana Drábková, Zbyněk Šimůnek, Ondřej Dostál, Richard Lojka, and Bronislava Vávrová are acknowledged for field and technical assistance. The research was supported by grant No. 227/2001 B-GEO-PřF of the Grant Agency of Charles University, Prague. The paper is part of the research program of the Institute of Geology, AS CR, Prague (No. AV0Z30130516).

\section{References}

Augusta, J. \& PokornÝ, V. 1950. Kritické poznámky k stegocefalím šlépějím ze spodního namurienu od Kyjovic. Věstník Královské české společnosti nauk, Tř́da mathematicko-přírodovědecká 6, 1-6.

Bockelie, J.F. 1994. Plant roots in core, 177-199. In Donovan, S.K. (ed.) The Palaeobiology of Trace Fossils. J. Wiley \& Sons, Chichester.

Braddy, S.J. \& BRIGgS, D.E.G. 2002. New Lower Permian nonmarine arthropod trace fossils from New Mexico and South Africa. Journal of Paleontology 76(3), 546-557.

Fillion, D. \& PickeRILL, R.K. 1990. Ichnology of the Upper Cambrian to Lower Ordovician Bell Islands and Wabana groups of eastern Newfoundland, Canada. Palaeontographica canadiana 7, 1-119.
Frey, R.W., Pemberton, S.G. \& Fagerstrom, J.A. 1984. Morphological, ethological, and environmental significance of the ichnogenera Scoyenia and Ancorichnus. Journal of Paleontology 58(2), 511-528.

HÄNTZSCHEL, W. 1962. Trace fossils and problematica, 177-245. In MOORE, R.C. (ed.) Treatise on Invertebrate Paleontology, part W (Miscellanea). Geological Society of America and University of Kansas Press, New York.

KeIGHLEY, D.G. \& PiCKeRILl, R.K. 1996. Small Cruziana, Rusophycus, and related ichnotaxa from eastern Canada: the nomenclatural debate and systematic ichnology. Ichnos 4, 261-285.

Klembara, J. 1997. The cranial anatomy of Discosauriscus Kuhn, a seymouriamorph tetrapod from the Lower Permian of the Boskovice Furrow (Czech Republic). Philosophical Transactions of the Royal Society of London B 352, 257-302.

Kukalová, J. 1965. Permian Protelytroptera, Coleoptera and Protorthoptera (Insecta) of Moravia. Sborník geologických věd, Paleontologie 6, 61-98.

Mangano, M.G., Buatois, L.A, Maples, C.G. \& West, R.R. (2002). Ichnology of a Pennsylvanian equatorial tidal flat; the Stull Shale Member at Waverly, eastern Kansas. Kansas Geological Survey, Bulletin 245, 1-133.

Maples, C.G. \& SutTNeR, L.J. 1990. Trace fossils and marine-nonmarine cyclicity in the Fontain Formation (Pennsylvanian: Morrowan/Atokan) near Manitou Springs, Colorado. Journal of Paleontology 64(6), 859-880.

Martínek, K., Dostál, O., DrábKová, J., Jelínek, F., Mikuláš, R., Nehyba, S., Šimưnek, Z., ŠtamberG, S. \& ZAJíc, J. 2004a. Paleoenvironmental changes and the Late Variscan development of the eastern Bohemian Massif: sedimentary and paleontological record of the Boskovice Basin. 15 pp. Final report of the research project GAUK 227/2001/B-GEO/PřF, Charles University, Prague.

MartíneK, K., DrábKová, J., Mikuláš, R., ŠimưneK, Z., S̆TAMBERG, S. \& ZAJíc, J. 2004b. Paleoenvironmental changes at the Carboniferous-Permian boundary: sedimentary and paleontological record of the Boskovice Basin, Czech Republic. Abstracts of the $10^{\text {th }}$ Coal Geology Conference, June 7-11, 2004.

Pemberton, S.G. \& Frey, R.W. 1982. Trace fossil nomenclature and the Planolites-Palaeophycus dilemma. Journal of Paleontology 56, 843-881.

PollARD, J.E. 1988. Trace fossils in coal-bearing sequences. Journal of the Geological Society of London 145, 339-350.

Pešek, J., Holub, V., Jaroš, J., Malý, L., MartíneK, K., ProuzA, V., Spudil, J. \& TÁsler, R. 2001. Geologie a ložiska svrchnopaleozoických limnických pánví v České republice. 244 pp. Český geologický ústav, Praha. 